NBER WORKING PAPER SERIES

\title{
MARKET STRUCTURE, OUTGROWER CONTRACS AND FARM OUTPUT. EVIDENCE FROM COTTON REFORMS IN ZAMBIA
}

\author{
Irene Brambilla \\ Guido Porto \\ Working Paper 11804 \\ http://www.nber.org/papers/w11804 \\ NATIONAL BUREAU OF ECONOMIC RESEARCH \\ 1050 Massachusetts Avenue \\ Cambridge, MA 02138 \\ November 2005
}

We wish to thank T. Jayne, J. Nijhoff, and B. Nsemukila for allowing us access to the Post Harvest Survey data collected by the Central Statistical Office in Lusaka, Zambia. We thank J. Altonji, R. Betancourt, M. Duggan, P. Goldberg, S. Jayachandran, A. Khandelwal, T. Miguel, R. Pande, M. Rosenzweig, M. Schündeln, C. Udry, and seminar participants at Berkeley, Di Tella, Lausanne, Maryland, Virginia, Yale, the Econometric Society Winter Meeting and the World Bank for useful comments and discussion. This project benefitted from a Research Budget Support grant from the World Bank. All errors are our responsibility.

(C) 2005 by Irene Brambilla and Guido Porto. All rights reserved. Short sections of text, not to exceed two paragraphs, may be quoted without explicit permission provided that full credit, including $\odot$ notice, is given to the source. 
Market Structure, Outgrower contracs and Farm Output. Evidence from Cotton Reforms in

Zambia

Irene Brambilla and Guido Porto

NBER Working Paper No. 11804

November 2005, Revised August 2009

JEL No. O12,O13,Q12

\begin{abstract}
This paper investigates the dynamic impacts of cotton marketing reforms on farm output in rural Zambia. Following liberalization and the elimination of the Zambian cotton marketing board, the sector developed an outgrower scheme whereby cotton firms provided credit, access to inputs and output markets, and technical assistance to the farmers. There are two distinctive phases of the reforms: a failure of the outgrower contracts, due to farmers' debt renegation, firm hold up, and lack of coordination among firms and farms, and a subsequent period of success of the scheme, due to enhanced contract enforcement and commitment. We find interesting dynamics in the sector. During the phase of failure, farmers were pushed back into subsistence and cotton yields per hectare declined. With the improvement of the outgrower scheme, farmers devoted larger shares of land to cash crops, and farm output significantly increased.
\end{abstract}

Irene Brambilla

Yale University

Department of Economics

37 Hilllhouse

P. O. Box 208264

New Haven, CT 06520-8264

and NBER

irene.brambilla@yale.edu

Guido Porto

Universidad Nacional de La Plata

Argentina

guido.porto@depeco.econo.unlp.edu.ar 


\section{Introduction}

In Africa, commodity markets were traditionally controlled by marketing boards - parastatal organizations that connected domestic farmers with product and input markets. Many of these public marketing boards - a bequeathal of British and French colonies - were eliminated during the agricultural liberalization of the 1990s. ${ }^{1}$ The Zambian cotton sector is a good example of this type of reforms. Until 1994, a public marketing agency, Lintco (Lint Company of Zambia), controlled the sector by selling inputs, buying cotton, giving credit, and facilitating access to technology, equipment and know-how. Lintco enjoyed monopsony power in purchases of farm output and monopoly power in sales of inputs. In 1994, the sector was liberalized and Lintco was privatized. Initially, the entry of Lonrho and Clark Cotton gave rise to a phase of regional private monopolies. During this phase, the firms developed outgrower schemes, vertical arrangements between firms and farmers whereby cotton ginners provided inputs on loans that were repaid at harvest time. In 1999, as additional entry and competition ensued, the outgrower scheme began to fail due to side selling of cotton seeds - farmers would take loans from one firm while selling to another. This caused a vicious circle: higher default rates led to higher costs to the companies, which in turn led to higher input prices and lower profitability for non-defaulting farmers. As a result, the scheme collapsed. ${ }^{2}$ The situation improved around 2001, when Dunavant (which had bought Lonrho) and Clark perfected the outgrower schemes to allow for tighter enforcement of contracts. ${ }^{3}$

In this paper, we investigate the dynamic effects of these marketing reforms on cotton yields at the farm level in rural Zambia. The outgrower schemes are a manifestation of the typical interlocking of transactions that constitutes a key element of the institutional framework that governs markets in developing countries (Bardhan and Udry, 1999). In

\footnotetext{
${ }^{1}$ See Bates (1981) for a comprehensive discussion of the politics of marketing boards in Africa. These marketing agencies set prices below world prices and utilized the revenue to improve the performance of the agricultural sector. After independence, the boards lost their role as support to agriculture and became highly inefficient institutions for redistribution and political gain.

${ }^{2}$ Kranton and Swamy (2008) develop a model where farmers can renege debt and side-sell and firms can hold up the farmers via lower ex-post prices.

${ }^{3}$ See Section 2 for details of the reforms.
} 
Zambia, the outgrower schemes facilitated the enforcement of farm contracts and the development of input, output and credit markets for the farmers. Given the available data and the changes in market structure in cotton, we are in a unique position to generate evidence on the role of contract enforcement, interlocked markets, and market structure (competition) on farm output and market choices.

We use farm surveys, the Post Harvest Surveys (PHS) of the Zambian Central Statistical Office. These surveys are repeated cross-sections of farmers with information on land allocation, yields, input use, and household characteristics. Our identification strategy relies on the comparison of cotton yields (relative to aggregate agricultural trends) across different phases of the reforms, conditional on both observed covariates (such as land, assets, farm and demographic characteristics) and unobserved farm effects such as overall land quality and overall cropping ability. In addition, we account for any biases caused by the compositional effects associated with entry and exit into cotton farming. ${ }^{4}$ Since more productive cotton farmers are more likely to allocate a larger fraction of their land to cotton production, we can use cotton shares, purged of observed covariates, as a proxy for the unobserved cotton effects that drive entry and exit (Rosenzweig and Schultz, 1987; Pitt et al., 1990).

The available data from the Post Harvest Survey span the period 1997-2002. While this prevents us from assessing the direct short-run impacts of the privatization of Lintco in 1994, we can explore the effects of the market dynamics that typically unravel after privatization, namely the heavy restructuring of the sector via entry and exit, the development of various outgrower schemes, and other factors. ${ }^{5}$ This paper is therefore not about the short-run benefits and costs of agriculture privatization in Africa, but rather about the medium-run impacts of the changes in market structure and contract enforcement mechanisms. Indeed,

\footnotetext{
${ }^{4}$ These compositional effects have been studied in the industrial productivity literature (Olley and Pakes, 1996; Pavcnik, 2002). In cotton farming, the composition bias appears if, for instance, lower productivity farmers exit during the failure phase. In this case, the average yield conditional on pre-reform cotton participation is lower than the average yield conditional on post-reform participation. Left unaccounted, this difference leads to a downward bias in the estimated impacts of the reforms (that is, to lower estimated losses in yields). During the success phase, entry of low productivity farmers may lead to lower estimated gains.

${ }^{5}$ This type of follow-up dynamics after liberalization are not specific to the Zambian case. They have been also observed in cashews in Mozambique (Welch et al., 2003), tobacco in Tanzania, coffee in Uganda, among other experiences.
} 
our findings reveal that, during the collapse of the outgrower contracts in 1999 and 2000, cotton adoption decreased and farm yields declined by between 40 to $45 \%$. In contrast, the subsequent success in the outgrower schemes induced farmers to increase land allocations to cotton, and caused yields per hectare to increase by $18 \%$.

The large impacts on cotton yields that we estimate in this paper attest to the relevance of grass-root level institutions that facilitate market interactions (Greif, 1993). Our analysis provides valuable lessons on the role of contracts, and mechanisms to enforce them, for development. In places where the judicial system does not work efficiently, well-functioning outgrower schemes are a viable alternative. Good outgrower schemes, in turn, depend on the balance between cooperation and competition among firms (Banerjee and Duflo, 2000; Kranton and Swamy, 2008). More competition is a pre-requisite for efficiency in market interlinkages between firms and farmers, but excessive or unregulated entry can lead to failures in contract enforcement.

Our work is also related to the literature on the modernization of agricultural value chains in developing countries. For instance, Gow and Swinnen (2001), Dries and Swinnen (2004), and Maertens and Swinnen (2009), among many others, study similar mechanisms to enforce contracts in transition economies (Slovakia, Croatia, Poland) and Africa (Senegal). Finally, our findings have implications for household income and poverty, critical issues in rural Zambia - where poverty rates exceed $80 \%$ of the population (Balat and Porto, 2006). Since yields per hectare more than doubled after the success of the outgrower contracts, sizeable drops in poverty should be expected (Maertens and Swinnen, 2009).

The remainder of the paper is organized as follows. In Section 2, we review the main reforms in cotton markets and the main expected impacts on yields. In section 3, we introduce the Post Harvest data and we describe our empirical model of crop choices and farm output. In Section 4, we discuss the results and assess the impacts of the marketing reforms on average farm yields. Section 5 concludes. 


\section{The Zambian Cotton Reforms}

With a population of 10.7 million and a per capita GDP of only 302 US dollars, Zambia is one of the poorest countries in the world. In 1998, for instance, the national poverty rate was $69.6 \%$, with rural poverty at $82.1 \%$ and urban poverty at $53.4 \%$. Given the characteristics of the soil, cotton can only be grown in three Zambian provinces, the Eastern, Central, and Southern provinces. Where it is grown, cotton is a major source of income. Data from

the Living Conditions Monitoring Survey of 1998 reveal that the share of cotton in income was $8.4 \%$ in the Central province, $9.5 \%$ in the Eastern province, and $2.8 \%$ in the Southern province.

Zambia began a process of economy-wide reforms in 1991. Based on Tschirley and Kabwe (2007) and Tschirley et al. (2009), we focus here on the elimination of the cotton marketing board. Traditionally, the Zambian cotton sector was heavily regulated. From 1977 to 1994, cotton marketing was controlled by the Lint Company of Zambia (Lintco), a parastatal organization. Lintco set the sale prices of certified cotton seeds, pesticides, and sprayers, as well as the purchase price of cotton lint. Lintco had monopsony power in cotton purchases and monopoly power in inputs sales and credit loans to farmers.

In 1994, Lintco was sold to Lonrho and Clark Cotton-firms with regional interests in cotton. The privatization was done in a way that facilitated the geographical segmentation of the market, with Lonrho active in the Center and Clark in the East. As a result, the initial phase of liberalization gave rise to geographical monopsonies rather than national oligopsonies.

At that moment, Lonrho and Clark Cotton developed outgrower schemes with Zambian farmers. In these outgrower programs, firms provided seeds and inputs on loans, together with extension services to improve productivity. The value of the loan was deducted from the sales of cotton seeds to the ginners at picking time. These schemes were based on "agents," firm employees that acted as extension and credit officers. Supposedly, the pass-through of international prices to the farmer was enhanced. Initially, repayment rates were high (around roughly 86\%) and cotton production significantly increased. We called this the outgrower introductory phase. 
By 1999, the expansion of cotton farming attracted new entrants in ginning and assembly. Instead of the localized monopsonies, competition ensued. Furthermore, independent cotton intermediaries emerged. These traders (who acquired inputs independently, distributed them to various farmers, purchased cotton lint, and sold it to the ginneries) made competition even more aggressive. Without any regulatory framework to control entry, the system entered a vicious circle and failed. Those firms that were not using outgrower schemes as well as some cotton intermediaries had incentives to offer higher net cotton prices to farmers who had already signed outgrower contracts with other firms (mostly Lonrho and Clark). This caused repayment problems and increased the rate of loan defaults. The loan repayment rate, for instance, dropped to around 60-65\%. In turn, firms raised loan prices and non-defaulting farmers ended up receiving a lower net price for their cotton production. The sector collapsed. We called this the outgrower scheme failure phase.

Partly as a result of this failure of the outgrower schemes, Lonrho exited the market and was acquired by Dunavant Zambia Limited (part of a U.S. multinational corporation). Dunavant and Clark Cotton actively worked to improve and expand the outgrower schemes. ${ }^{6}$ Two innovations took place. First, firms adopted identifying labels on the cotton bags given to farmers to store production after harvest and committed to only purchase cotton bags with their own labels. This helped eliminate most of the independent traders that contaminated the market during the failure phase. Second, Dunavant introduced the "Distributor System." The firm provided inputs which were allocated to farmers by a distributor, an independent agent (not a firm employee), that grew cotton himself. He prepared individual contracts with the farmers, was in charge of assessing reasons for loan defaults (being able, in principle, of condoning default in special cases), and renegotiated contracts in incoming seasons. The Distributor had discretion on the number of farmers under his control. Clark kept the more traditional agent/employee-based system but worked to extend coverage. Both Dunavant and Clark (and others) also expanded the production network, thus facilitating access for a wider array of smallholders. Both systems worked well, and repayment rates increased from

\footnotetext{
${ }^{6}$ Some of the other minor players that had recently entered the market also used outgrower schemes, although they arguably free-rode on the schemes successfully developed by the major players, Dunavant (Lonrho) and Clark.
} 
$65 \%$ to $90 \%$ (Tschirley and Kabwe, 2007). The sector boosted. We call this the outgrower scheme success phase.

\section{Data and Estimation Strategy}

In this section, we describe the data and we develop the empirical model to estimate the dynamic impacts of the different phases of the cotton marketing reforms on cotton yields.

\subsection{The Post Harvest Survey}

We use the Post Harvest Survey (PHS), farm surveys collected by the Zambian Central Statistical Office (CSO). We have annual repeated cross-sectional data available for the period 1997-2002. The survey is representative at the national level, but in this paper we only use the data pertaining to cotton producing regions: the Central, Eastern, Southern and Lusaka provinces. The PHS gathers information on land tenure, land usage (allocation), output in physical units, household characteristics (demographics, housing infrastructure), and limited data on farm assets and inputs.

Table 1 provides an overview of the relevant sample sizes, by year and by province. In a given survey, around 600-700 households were interviewed in the Central province, 1,200, in the Eastern province, 800 in the Southern province, and 200 in Lusaka. Table 2, which reports the fraction of farmers engaged in cotton production, confirms that the major cotton producing areas are indeed the Eastern province (where, for example, $39 \%$ of farmers produced cotton in 2002), the Central province (20\%), and the Southern province (12.8\%). There were some, but not many, cotton producers in Lusaka and, in the remaining provinces, the percentage of households that grow cotton was virtually zero.

Table 2 also reveals some of the interesting dynamic patterns that we explore below. During 1997 and 1998, the introductory phase, cotton participation was relatively stable in all provinces (although a declining pattern may be discernible). The failure phase (1999-2000) shows lower participation rates, particularly in 2000. In the Central province, for instance, cotton participation dropped from 22.6\% in 1998 to 10.3\%. Similarly, participation 
declined from 32.7 to 20.4 percent in the Eastern province, from $10.7 \%$ to $4.3 \%$ in the Southern provinces, and from $3.3 \%$ to $0.4 \%$ in Lusaka. The success phase (2001-2002) instead correlated with strong entry into cotton: the percentage of cotton growers increased significantly in all provinces: from 10.3 to $20.2 \%$ in the Central province, from 20.4 to $39 \%$ in the Eastern province, from 4.3 to $12.8 \%$ in the Southern province, and from 0.4 to $8.2 \%$ in Lusaka.

Similar conclusions emerge from the inspection of the intensity of participation. In Table 3, we report data on the fraction of land allocated to cotton, for all farmers (panel a) and for cotton farmers (panel b). We confirm the prevalence of cotton in the Eastern province (with an average land share of 14.6 percent in 2002), in the Central province (8.5\%), and in the Southern province $(5.1 \%)$. In panel b), notice that, conditional on cotton farming, the average share of land allocated to cotton is relatively similar across regions: $37.3 \%$ in the East, $39.1 \%$ in the Center, and $38.9 \%$ in the South. The dynamics of cotton adoption are also revealed in Table 3. The fraction of land allocated to cotton sharply declined in 1999 and 2000 (the failure phase) and then increased in 2001 and 2002 (the success phase).

In Table 4, we report the evolution of cotton yields per hectare, the focus of our investigation. The figures are in logarithms, so that changes from one year to the other can be interpreted as growth rates. At the national level, cotton yields increased from 1997 to 1998, and then declined during the failure phase of 1999-2000. In fact, yields dropped by $32 \%$ from 1998 to 2000 (although average yields in 2000 were comparable to average yields in 1997). During the success phase, average yields significantly recovered.

\subsection{The Empirical Model}

To estimate the impacts of the reforms on cotton yields, we let $y_{h t}^{c}$ denote the volume of cotton production per hectare (in kilograms) produced by household $h$ in period $t$. The $\log$ of output per hectare is given by

$$
\ln y_{h t}^{c}=\mathbf{x}_{h t}^{c \prime} \beta_{c}+\alpha_{1} F_{t}^{1}+\alpha_{2} F_{t}^{2}+I_{t}+\eta_{h t}+\phi_{h t}+\epsilon_{h t}^{c},
$$


where $\mathbf{x}_{h t}^{c}$ is a vector of observed controls, $F_{1}$ and $F_{2}$ capture the different phases of the marketing reforms, $I_{t}$ are year effects, and $\eta_{h t}, \phi_{h t}$ and $\epsilon_{h t}$ are different farm effects that comprise the error term. We first discuss the model, equation (1), and we then explain our identification strategy.

In (1), $\mathbf{x}_{h t}^{c}$ is a vector of household determinants of cotton yields: age and gender of the household head, household size and household demographics, general farm and household characteristics (male composition, aggregate fertilizer use), assets, the size of the land allocated to cotton, farm size, and district dummies. ${ }^{7}$ We also include prices, exploring models with the international price of cotton relative to the district maize price and the pre-planting cotton price (relative to maize prices).

We measure the impacts of the marketing reforms with two variables, $F_{t}^{1}$ and $F_{t}^{2} . F_{t}^{1}$ is a dummy variable that captures the second period of the reform, the outgrower scheme failure phase of 1999-2000, and $F_{t}^{2}$ is another dummy that captures the third period of the reform, the outgrower scheme success phase of 2001-2002. The impacts of these phases of the reform are measured relative to the excluded category, which is the outgrower scheme introductory phase of 1997-1998. It is important to note that the introductory phase already showed significant improvements in performance vis-à-vis the marketing board era (Tschirley and Kabwe, 2007). Since the introductory phase is our base period, our estimates are a lower bound for the impacts of the privatization.

The variables $F_{1}$ and $F_{2}$ are aggregate indicators of the different phases of the reforms and therefore include several mechanisms through which these marketing reforms affect yields: input prices, output prices, and access to credit, improved inputs (sprayers, seeds, equipment), and technology. Yields are affected for two main reasons. First, the reforms affect input use like labor, seeds and pesticides and, especially, input quality and effort (farmers may neglect the crop during the failure phase and, conversely, exert more effort and

\footnotetext{
${ }^{7}$ Briefly, the determinants of cotton yields include: the quantity and quality of variable inputs; human capital; the use of credit and the availability of collateral (Eswaran and Kotwal, 1986; Dercon, 1996); technology (Foster and Rosenzweig, 1995; Conley and Udry, 2010); the use of improved tools (tractors or sprayers); local infrastructure and public goods; agricultural extension services; social capital and learning externalities; the trade-off between profitability and risk (Rosenzweig and Binswanger, 1993) and the different attitudes towards risks (Binswanger and Sillers, 1983; Dercon, 1996); missing food markets (de Janvry et al., 1991; Fafchamps, 1992; Jayne, 1994).
} 
secure higher quality inputs during the success phase). Second, yields are affected because of the improved efficiency in input combination allowed for by enhanced access to credit, technology, and information. In (1), $\alpha_{1}$ and $\alpha_{2}$ capture a mixture of all these effects - price, credit, input use, information, and efficiency. Due to the nature of our data, we can assess the overall significance of all these factors, but we are unable to separately identify the relative importance of each of the components.

We now turn to a discussion of our identification strategy. Since we measure the different phases of the reforms with combinations of year dummies, identification of $\alpha_{1}$ and $\alpha_{2}$ requires that we control for the year effects $I_{t}$. These effects capture aggregate agricultural effects and other shocks that are common to all farmers in a given period $t$ and that may confound the impacts of the reforms.

Further, identification of $\alpha_{1}$ and $\alpha_{2}$ also requires a discussion of the unobserved heterogeneity in the model. This includes regional effects, like market access, local infrastructure, and local knowledge, which can be controlled for with district dummies. More importantly, the unobserved heterogeneity includes three different idiosyncratic farm level unobservables: a farm effect, $\eta$, a cotton-specific effect, $\phi$, and a random shock $\epsilon$. The farm effect $\eta$ captures all idiosyncratic factors affecting general agricultural productivity in farm $h$ that are observed by the farmer when making input and land allocation decisions but not by the econometrician (and thus are not included in $\mathbf{x}$ ). For instance, land quality, know-how, and other factors that affect yields in all crops are components of $\eta$. The cotton-specific effect $\phi$ is a combination of unobserved factors that affect yields in cotton, including ability and expertise in cotton husbandry and suitability of the land for cotton farming. Finally, since the random shock $\epsilon$ is unobserved by the farmer, it does not affect the farmers' decisions; unlike $\eta$ and $\phi, \epsilon$ can be left unaccounted for.

There are two problems with the household effects $\eta$ and $\phi$. First, some of the variables in $\mathbf{x}$ as well as the reform variables $F_{1}$ and $F_{2}$, which include factors such as effort, input use (quality of seeds), or technical advice, may be correlated with $\eta$ and $\phi$. For example, farmers with more farming ability may focus more on the details of cotton production and exert better effort or apply more and better fertilizer to the cotton crop; or, they could seek 
higher quality, more regular technical assistance. Second, entry and exit into cotton farming depend on $\phi$ since farmers' decisions on land allocation may be based on factors like land quality or farmer ability. This entry/exit component can affect the estimates of the reform dummies by altering the composition of farmers that produce cotton in each time period (see below). ${ }^{8}$

To account for this unobserved heterogeneity, we need additional modeling. Our empirical approach embeds two strategies: we use trends in maize yields to control for both the overall agricultural effects, $I_{t}$, and the overall farm effects, $\eta$; and we use the share of land devoted to cotton to control for cotton-specific effects, $\phi$.

\subsubsection{Trends in Maize Yields}

Our first strategy is to difference out the effects of time-varying aggregate effects in agriculture, $I_{t}$, and idiosyncratic farm effects, $\eta_{h t}$, using a model of maize yields. To implement it, we assume that yields per hectare in maize, $y_{h t}^{m}$, are given by

$$
\ln y_{h t}^{m}=\mathbf{x}_{h t}^{m \prime} \beta_{m}+I_{t}+\eta_{h t}+\epsilon_{h t}^{m} .
$$

Here, maize yields depends on covariates $\mathbf{x}_{h t}^{m}$ (which include regional effects), the agricultural year effects, $I_{t}$, and the farm effects $\eta_{h t}$. In (2), we assume that all the maize-specific effects are accounted for by $I_{t}$ and $\eta_{h t}$, a reasonable assumption since Zambian farmers have traditionally grown maize for home consumption. Subtracting (2) from (1), we get

$$
\ln y_{h t}=\ln \left(y_{h t}^{c} / y_{h t}^{m}\right)=\mathbf{x}_{h t}^{\prime} \beta+\alpha_{1} F_{t}^{1}+\alpha_{2} F_{t}^{2}+\phi_{h t}+\epsilon_{h t} .
$$

In (3), the vector $\mathbf{x}_{h t}$ is the same as in (1). Moreover, it also includes the relative price of cotton to maize at the district level and regional dummies, which are not cancelled out in the differencing because we allow the regional effects to affect cotton and maize yields differently. For example, to the extent that the district dummies capture local market access

\footnotetext{
${ }^{8}$ If these idiosyncratic effects were fixed over time, panel data would allow us to account for both $\eta$ and $\phi$ with farm fixed effects. The Post Harvest Survey, however, is a repeated cross section of farmers and thus both $\eta$ and $\phi$ are indexed by $h$ and $t$.
} 
effects, we allow marketing conditions to affect cotton (a cash crop activity) and maize (a mostly subsistence crop) differently.

The maize-differencing strategy requires that all cotton producers be maize producers as well. In the case of Zambia, we claim that this strategy works because maize is the major staple crop and is thus produced by all (cotton) farmers. ${ }^{9}$ In fact, maize production is fundamentally linked to the food security needs of the family: farmers produce maize and only when the food needs are secured do they consider growing cotton. Table 5, which reports the percentage of households that grow maize, provides evidence supporting this. We show that in the cotton provinces, maize is grown by virtually all households. Participation in maize production is always above $90 \%$ in the relevant regions, and, in the Eastern and Lusaka provinces, the percentage of maize producers is nearly 100\%. Table 6 reports evidence that further supports our differencing strategy. We report the percentage of farmers that grow maize, conditional on being cotton growers. These shares are nearly $100 \%$ in the three main cotton-growing provinces.

There are two additional identification assumptions that we can check. First, our approach assumes that the agricultural effects, $I_{t}$, affect cotton and maize yields proportionately (due to the logarithmic specification). In other words, the agricultural effects are assumed to have the same effect on the growth of cotton and maize output per hectare so that we can use the trend in maize yields to predict the counterfactual cotton yields in the absence of the reforms. To support this assumption, we can compare the growth rate in maize with growth rates in other crops because, under the maintained hypothesis, these trends should be similar across crops. Figure 1 supports this argument. Each panel compares the trend in yields per hectare in maize (solid line) with the trend in alternative crops like sorghum, millet, sunflower, groundnuts, and mixed beans (broken line). We observe that, with the sole exception of groundnuts in 2001, the trends in all these crops are very similar. In the regression analysis, we use maize as control because, unlike the other crops, all households produce it.

\footnotetext{
${ }^{9} \mathrm{~A}$ key characteristic of cotton farming in Zambia is its scale: cotton is grown by smallholders, family farms endowed with small farms, usually smaller than four hectares and with an average size of around 2 hectares.
} 
In addition, under the maintained hypothesis, we should observe similar trends in cotton and maize in Zambia before the marketing reforms of 1994 and we should also observe similar trends in neighbor countries like Malawi, Zimbabwe and Mozambique - that are likely to be similar to the cotton regions in Zambia. Figure 2 displays these trends. We report data taken from FAOStat for the period 1985-1995 so as to present some historical data before the agricultural liberalization that took place in Africa in mid-1990s. It can be seen that the growth rate of cotton and maize yields are quite similar, especially in Zambia, Malawi and Zimbabwe.

The other identifying assumption of our model is that the cotton reforms did not affect maize yields. Theoretically, these reforms could affect output in all crops via spillovers in resource allocation (labor, effort, fertilizers, pesticides), wealth effects, capital accumulation and credit and financial constraints. To the extent that the regression includes farm characteristics like labor availability, agricultural tools, and land allocation, these spillovers will be partially accounted for. But since $\mathbf{x}$ cannot account for spillovers in input quality or effort, it is thus plausible for $\alpha_{1}$ and $\alpha_{2}$ to capture a mixture of impacts on cotton and maize yields. There is a simple way to rule this out: if the reforms did not affect maize yields, then the trends in yields in 'reform' provinces (i.e., provinces where cotton is grown) should be similar to trends in 'non-reform' provinces (i.e., provinces where cotton is not grown). These trends are plotted in Fig. 3. The solid line corresponds to the trend in maize productivity in reform provinces and the broken line, to the trend in non-reform provinces. It can be seen that these trends are indeed comparable across the whole period (except for 2002). Even if it is not possible to entirely rule out the spillover effects from the cotton reforms to maize farming, Fig. 3 strongly suggests that these spillover effects will be fairly small in our analysis.

Finally, our strategy requires that the only shock to cotton captured by $F_{1}$ and $F_{2}$ be the marketing reform. One possible confounding cotton-specific shock would be changes in international prices; these prices are, however, already controlled for in our regressions. In the available reviews of agriculture in Zambia during this period, there is no evidence of other relevant shocks to cotton, except for the marketing reforms that we are investigating. 


\subsubsection{Entry and Exit in Cotton Farming}

The cotton specific effects $\phi_{h t}$, which include the suitability of the land for cotton production and unobserved know-how in cotton husbandry, raise additional concerns. Omitting $\phi$ may induce correlation between some variables in the vector $\mathbf{x}$ and the error term in the model. The choice of inputs, such as labor or pesticide use, depends on $\phi$ (so that unobserved productivity may be correlated with input use). The estimates of the impacts of the reforms, $\alpha_{1}$ and $\alpha_{2}$ will also be biased. The unobserved heterogeneity in $\phi$ leads to different entry-exit decisions in cotton farming, which in turn alters the composition of the group of farmers that produce cotton in each of the reform phases. This compositional bias, which has been extensively studied in industrial productivity analysis (Olley and Pakes, 1996; Pavcnik, 2002), can be fixed by modeling entry and exit.

With fixed costs in cotton production, cotton will only be profitable if productivity is high enough. As a result, there will be a cut-off (which depends on prices, market conditions, infrastructure) such that farmers with productivity above this cut-off will enter the market and farmers below the cut-off will not enter (or exit, if they were in the market already). When the reforms increase the profitability of cotton, for instance, lower productivity farmers may be able to enter the market. Failure to control for this may lead to inconsistently lower estimates of average yields at the farm level, thus leading to a downward bias in the estimates of the (positive) impacts of the reforms. In contrast, in periods of induced exit, farmers with lower unobserved productivity will be more likely to abandon cotton production. In consequence, measures of average cotton yields that do not control for these dynamic effects may be artificially high, thus leading to downward biases in the estimates of the (negative) impacts of the reforms.

Figure 4 clarifies these dynamics. The graph shows relative cotton productivity $y$ as a function of unobserved cotton-specific effects $\phi$-for simplicity of exposition we assume that the exogenous part of $\mathbf{x}$ is the same for all farmers and that the only difference across farmers is given by $\phi$. Yields, or land productivity, are increasing in $\phi$ since better land quality or higher cotton skills lead to higher output (for a given usage of other inputs). The line denoted $y_{0}$ represents the cotton yields function before the reform. The horizontal line 
at $\bar{y}$ denotes the cut-off, which, for simplicity, does not vary with the reforms. It follows that we can determine a cut-off for the unobservables, denoted $\bar{\phi}$. The average yield before the reform is, say, $E\left(y_{0}\right)$, the average of $y$ conditional on $\phi>\bar{\phi}$.

Consider the effects of the failure of the outgrower scheme. If yields are negatively affected, the yields curve shifts down to $y_{1}$. Assuming a fixed output cut-off $\bar{y}$, the cut-off for the unobservables increases to $\bar{\phi}^{\prime} .{ }^{10}$ This induces the 'exit' of those farmers with relatively low levels of $\phi$, between $\bar{\phi}^{\prime}$ and $\bar{\phi}$. Average yield, conditional on participation, drops to $E\left(y_{1}\right)$. However, the decline in individual yields is larger. The right quantity is the average productivity, computed along the curve $y_{1}$, and integrating over values of $\phi$ above the cutoff before the reform, $\bar{\phi}$. This is given by $E\left(y_{r}\right)$. The empirical model in equation (3) estimates a change in average yields given by $E\left(y_{0}\right)-E\left(y_{1}\right)$ which is a downward biased estimate of the true effects at the farm level, given by $E\left(y_{0}\right)-E\left(y_{r}\right)$. To correct these estimates, we need to account for the role of unobserved cotton effects.

Our solution to this problem is to construct proxies for the unobserved cotton-specific effects $\phi$. Our method exploits the idea that since households with high $\phi$ are more productive in cotton, they are also more likely to devote a larger share of their land to cotton production. This means that we could use land cotton shares as a proxy for the unobservable $\phi_{h t}$ in (3).

A good proxy needs to be a good predictor of $\phi$. Since, in practice, cotton shares depend on various covariates besides cotton-specific effects that also affect yields (e.g., family characteristics), we need to purge these shares of the part explained by observed determinants of cotton choices. To accomplish this, our proxy for $\phi$ is the residual from a model of cotton land shares. Conceptually similar ideas have been adopted by Rosenzweig and Schultz (1987), on fertility, and Pitt et al. (1990), in the health literature.

The model for the fraction of land allocated to cotton, $a_{h t}^{c}$, is:

$$
a_{h t}^{c}=\mathbf{z}_{h t}^{\prime} \gamma_{t}+v_{h t}
$$

where $\mathbf{z}$ is a vector of regressors. We estimate the model with OLS and Tobit methods (to account for the left-censoring of $a_{h t}^{c}$ at zero). In $\mathbf{z}$, we include all the regressors in the

\footnotetext{
${ }^{10}$ Allowing for $\bar{y}$ to change after the reforms leaves our intuition unchanged.
} 
vector $\mathbf{x}$ of the cotton yield model (3), but we exclude pesticide and fertilizer use (basal, top-dressing) because these are variable inputs and are thus a direct determinant of yields but not of crop choice. Notice, however, that the purpose of this assumption is to avoid achieving identification only from functional forms (non-linearities) in the Tobit models, but that it is not a critical piece of our model. We experiment with three proxies $\widetilde{\phi}$ :

$$
\widetilde{\phi}_{h t}=\left\{\begin{array}{c}
a_{h t}^{c}-\mathbf{z}_{h t}^{\prime} \widehat{\gamma}_{t}^{o l s} \\
a_{h t}^{c}-\mathbf{z}_{h t}^{\prime} \widehat{\gamma}_{t}^{t o b i t} \\
g_{t}\left(a_{h t}^{c}-\mathbf{z}_{h t}^{\prime} \widehat{\gamma}_{t}^{\text {tobit }}\right) .
\end{array}\right.
$$

The first and second proxies are just the residuals of OLS and Tobit regressions of $a_{h t}^{c}$ on $\mathbf{z}_{h t}$, respectively. In these cases, the proxy $\widetilde{\phi}$ enter linearly into (3). In the third experiment, we allow our proxy to be a nonlinear function of the Tobit residuals so that the cotton yields model is

$$
\ln y_{h t}=\mathbf{x}_{h t}^{\prime} \beta+\alpha_{1} F_{h t}^{1}+\alpha_{2} F_{h t}^{2}+g_{t}\left(a_{h t}^{c}-\mathbf{z}_{h t}^{\prime} \widehat{\gamma}_{t o b i t}\right)+\widetilde{\epsilon}_{h t} .
$$

To estimate (6), we use a partially linear model (Robinson, 1988).

Before turning to the results, we should mention three methodological issues. First, since we use data on all households to estimate (4), this model does not suffer from compositional biases. Second, the allocation of land to cotton depends on the reforms as well as on aggregate agricultural effects and international prices. However, a specification of (4) that that includes $\mathbf{z}, F_{1}, F_{2}, I_{t}$ is not identified. In addition, since the maize share equation contains essentially the same information as the cotton share equation, the differencing strategy used in the yields model will not work in the shares model. This means that we will not be able to identify the effects of the reforms on land allocation, but we will be able to control effectively for $\phi$ in the yields model. ${ }^{11}$ Finally, $\widetilde{\phi}$ may be an imperfect proxy for $\phi$ if there are unobservables in the share equation that also affect yields. We address this issue below.

\footnotetext{
${ }^{11}$ In practice, to improve the quality of our proxy, we estimate a different regression function for cotton shares in each of the six years from 1997 to 2002. Notice that $\widehat{\gamma}$ and $g_{t}$ are indexed by $t$ in (5).
} 


\section{Results}

Our benchmark results are reported in Table 7. Columns (1) and (2) report estimates of equation (1), that is, a simple model of yields per hectare that does not control for unobservables such as $I_{t}, \eta_{h t}$ and $\phi_{h t}$. In these regressions, we use data from the three main cotton provinces, the Central, the Eastern, and the Southern provinces.

We begin by briefly discussing the main results regarding the observed covariates in $\mathbf{x}$. We find that small farms are more productive in cotton (the variable 'farm type' is a dummy equal to 1 for large farmers). There is also evidence in favor of decreasing returns to scale in cotton since there is a negative association between the size of land allocated to cotton and cotton yields. In addition, households with male heads and households with large families are more productive in cotton. Assets (such as ploughs or livestock) are positively associated with yields. The effects of inputs such as basal and top-dressing fertilizers (which are utilized in maize cultivation rather than in cotton) are not as strong as expected. Note that our controls for inputs (labor, fertilizers) are imperfect and should thus be interpreted as controls for farm characteristics. In these regressions, we include the international price (relative to the district price of maize). Prices have a positive impact on yields.

The dynamics of cotton yields are closely linked to the dynamics in market structure: compared to the introductory phase, yields are lower in the failure phase and higher in the success phase. In this simple model of cotton yields, yields per hectare declined by $11.3 \%$ (column 2) in the failure phase, and increased by $14.1 \%$ during the success phase.

Columns (3) to (6) report results from equation (3), controlling for agricultural effects $I_{t}$ and unobserved heterogeneity $\eta_{h t}$. In (3) and (4), we include the international price of cotton, while in (5) and (6), we instead use pre-planting cotton prices. Consider first the models that include international prices. The estimated impacts of the marketing reforms are significantly larger, especially during the failure phase. In this case, yields declined by $40.4 \%$ (column 4) instead of by $11.3 \%$ (column 2). There are two reasons for this large difference. First, there is a positive aggregate trend in agricultural yields (net of the effects of covariates) from the introductory to the failure phase. Second, some of the components of $F_{1}$, such as effort, prices or technical advice, are correlated with ability or land quality $(\eta)$. 
In consequence, high-ability farmers or farmers with better land may be able to sustain high yields even in the collapse of the outgrower scheme. If so, part of the effects of farming ability or land quality that are captured by $\eta$ are being attributed to $F_{1}$ so that the estimate of $\alpha_{1}$ in column (2) is biased down. The increase in yields during the success phase, after accounting for aggregate agricultural effects and $\eta$, was $18.1 \%$ (column 4), as opposed to $14.1 \%$ (column 2). These differences are not statistically significant. When comparing the failure and success phases, however, our estimates indicate that cotton yields per hectare in fact increased by a whopping $58.5 \%$. Notice that these estimates take the introductory phase as the base period. Since the introductory phase already showed improvement in performance with respect to the pre-privatization period, the gains from the overall liberalization can be quite large. ${ }^{12}$

By including international cotton prices as regressors, we control for exogenous shocks to cotton prices that may contaminate our estimates. Notice that this strategy assumes that the pass-through rate from firms to farmers only changes as a result of the reforms. Under this assumption, the effects of pass-through changes are embedded in $\alpha_{1}$ and $\alpha_{2}$. To explore the opposite case in which the pass-through rate is not affected by the reforms but instead responds to exogenous changes in international prices, we include the pre-planting cotton price (announced each year by Dunavant) relative to the district maize price. Our results, reported in Columns (5) and (6), remain essentially unchanged. This suggests that, while in practice pass-through rates are likely to change in part due to the reforms and in part due to changes in international prices, these differences are not playing a major role in the Zambian experience.

Why are these impacts so large and what do they mean? They are large because of two main reasons. The dummies $F_{1}$ and $F_{2}$ that measure the phases of the reform comprise various simultaneous channels, each contributing a bit to the overall gains. These channels include net prices (input prices and product prices), credit prices (interest rates on loans), input use like seeds, fertilizers, pesticides (both in quantity, quality), technical advice, equipment use (sprayers, tractors), and efficiency in input combination. More importantly,

\footnotetext{
${ }^{12}$ Note that our estimates could be contaminated by a reporting bias by farmers. This bias would be generated by farmers who side-sell, thus strategically reporting lower production than they in fact achieved. This would negatively bias estimates of yields during periods of credit crisis and positively bias the subsequent increase.
} 
the reforms implied drastic changes in market conditions in a situation of extremely low pre-reform yields. This indicates that farmers were producing well within the production possibility frontier. ${ }^{13}$

Our results highlight the interaction between competition and the outgrower schemes in improving performance among cotton smallholders. While contract farming is important to interlock markets and allow farmers to participate in cotton production, a successful enforcement of those contracts is needed (Greif, 1993). In the case of Zambia, a period of unrestricted entry of firms and intermediaries during the failure phase encouraged cotton side-selling and a subsequent collapse of the scheme. In part because of this, some of the incumbent firms (Dunavant and Clark) devoted resources to improve and extend the outgrower schemes - by developing, for instance, the Distributor Farmer System - and to foment coordination and commitment among them-by adhering to the bag label system, for instance-(Banerjee and Duflo, 2000; McMillan and Woodruff, 1999). Smallholder performance, in the end, was significantly improved, with implications for poverty alleviation and food security. While our farm survey does not collect monetary information, it is reasonable to expect large impacts on poverty following a doubling of yields in the success phase (Maertens and Swinnen, 2009).

We turn now to the compositional effects induced by entry and exit into cotton farming. In Table 8, we report the results with the entry and exit correction. ${ }^{14}$ Column (1) reproduces the estimates from column (4) of Table 7, which does not include controls for $\phi$. Columns (2) and (5) use a Tobit model to estimate the selection equation, columns (3) and (6) use a linear model, and columns (4) and (7) use the partially linear, Robinson (1988) model. Model 1 and Model 2 in Table 8 differ in the list of covariates: both models share the same regressors, but Model 1 measures assets (harrows and ploughs) in monetary units and Model

\footnotetext{
${ }^{13}$ It is fairly common to find large returns to capital (excluding risk) as well as productivity gains or losses from economic policies in developing countries. In Ghana, Conley and Udry (2010) and Udry and Anagol (2006) find real returns ranging from 250 to $300 \%$ (in the adoption of new technology in pineapples) or from 30 to $50 \%$ (in food crops). Similarly, a survey by Banerjee and Duflo (2005) reports returns to capital of $52 \%$ in rural India, $78.5 \%$ in rural Pakistan, $80-125 \%$ in Thailand, $80-100 \%$ in Bangladesh, and $34-68 \%$ in Kenya and Zimbabwe. Finally, McKenzie and Woodruff (2006) report returns to capital of $5-15 \%$ per month in Mexico.

${ }^{14}$ To save space, we do not report the estimates of (4). See the working paper version for details.
} 
2 measures them in physical units. To account for the fact that the model includes an estimated regressor, $\widetilde{\phi}$, we estimate the standard errors with a bootstrap procedure with 100 repetitions. In each loop of the bootstrap, we estimate (4), recover $\widetilde{\phi}$, and plug it in (3).

Accounting for the compositional effects associated with entry and exit does not affect our qualitative conclusions: yields declined during the failure phase $\left(\alpha_{1}\right.$ is negative and significant) and increased during the success phase ( $\alpha_{2}$ is positive and significant). Furthermore, these results are robust to the selection model used to build the proxy for $\phi$, i.e., the linear model, the Tobit model or the Robinson model.

Compositional effects seem to matter more in periods of exit than of entry. In Table 8, the estimates of $\alpha_{1}$ (the failure phase) range from $42.9 \%$ (column 2) to $44.8 \%$ (column 6), which are larger than the decline of $40.4 \%$ in column (1). This means that although the average aggregate output per hectare in the economy declined by $40.4 \%$, the average output of a typical cotton farm declined instead by 43-45 percent. In other words, yields are, on average, 3 to $5 \%$ higher than what they would be had the most unproductive farmers (in terms of $\phi$ ) not exited the market. These differences, however, are not statistically significant.

During the success phase, the control for $\phi$ does not seem to affect the estimates of $\alpha_{2}$. In all our specifications in columns (2) to (7) of Table 8, the estimates of $\alpha_{2}$ are similar to those from the model that does not correct for $\phi$ (column 1 and Table 7). One possible explanation is that entry is more costly than exit. When unobservables $\phi$ are such that cotton becomes unprofitable, farmers may exit at no significant cost. Instead, when cotton becomes profitable, there might still be impediments to entry. Qualification for an outgrower contract is perhaps the major barrier to entry. If a farmer exited due to default, re-entry may indeed be costly.

So far, we have assumed that $\widetilde{\phi}$ is a good proxy for $\phi$ in the sense that once $\widetilde{\phi}$ is included in the model there is no leftover correlation between $\mathbf{x}, F_{1}$ and $F_{2}$, and $\phi$. If this is not the case, our proxy becomes an indicator and needs to be instrumented with another proxy/indicator. In the absence of instruments, we can think about $\widetilde{\phi}$ as an error-ridden variable, $\widetilde{\phi}=\left(a_{h t}-\right.$ $\left.\mathbf{z}_{h t}^{\prime} \gamma\right)+u_{h t}$, where $u$ is measurement error (Altonji, 1986). In this setting, we can estimate the model under different assumptions about the variance $\sigma_{u}^{2}$ and safely ignore the problem 
if the estimates of the model are relatively insensitive to it. In Table 9, we report estimates of $\alpha_{1}, \alpha_{2}$ from equation (3) under several different assumptions about $\sigma_{u}^{2}$, from 1 to 300 (cotton shares are measured in percentages, from 0 to 100). Clearly, our estimates of $\alpha_{1}$ and $\alpha_{2}$ remain largely unaffected by the potential measurement error.

To end, we check the robustness of our results to the definition of the phases of the reforms. The dynamics generated by the elimination of the marketing board are generally complex, and it may be arbitrary to assign specific years to different phases. In consequence, we re-estimate the model using two alternative definitions. First, we redefine the failure phase to include only the year 2000 (dummy denoted $R^{1}$ ) thus moving the year 1999 to the introductory phase. As shown in section 3, the drop in the share of land allocated to cotton as well as cotton yields declined much more markedly in 2000 than in 1999. The success phase still includes 2001 and 2002 (with dummy defined by $R^{2}$ ). In our second redefinition, we measure the impacts of the reforms by including year dummies, thus allowing the effects of the reforms to vary year by year.

Table 10 reports the results. In columns (1) to (3), we use Model 1 (measuring assets in monetary units) in the estimation of $a_{h t}^{c}$; in columns (4) to (6) we adopt instead Model 2 (assets in physical units). In both cases, we use Tobits in (4). Our qualitative conclusions remain unaffected. The collapse of the outgrower scheme led to a decline in yields in 2000 (of around $54 \%$ in both specifications). Also, the success phase led to an increase in yields of $18 \%$. More detailed patterns can be discerned when we use year dummies to measure the different phases of the reforms. Compared to 1997, we find that cotton yields first increased in 1998 and declined in 1999, back to 1997 levels. We still find a large decline in yields in 2000, of around 41\%. During the success phase, yields followed an increasing trend: output per hectare was $15.2 \%$ higher in 2001 than in 1997, and $43.3 \%$ higher in $2002 .{ }^{15}$

\footnotetext{
${ }^{15}$ We also assessed the robustness of the results to the inclusion of Lusaka growers in the sample. Since in fact there are fewer cotton growers in Lusaka, the results are insensitive to this alternative sample. In addition, we run different models for the three major cotton provinces. Results suggest stronger effects in the Center and East than in the South.
} 


\section{Conclusions}

This paper investigated the dynamic impacts of marketing reforms in cotton on farm yields in rural Zambia. The reforms originate in the elimination of the Zambia Cotton marketing board in 1994. Typically, this type of privatization episodes not only have short-run effects but also medium to long-run impacts through reallocation of incumbent firms, entry and exit of firms, market creation and destruction (for inputs, outputs and credit), and contract enforcement mechanisms (the outgrower schemes). While the available data do not span the privatization period per se, we are able to explore the follow-up market dynamics of the cotton reforms, especially the failure phase of 1999-2000 (characterized by the collapse of the outgrower schemes) and the subsequent success phase of 2001-2002 (characterized by the improvement in the outgrower schemes).

We found interesting dynamic effects of the marketing reforms. Compared to the introductory phase of 1997-1998, the failure of the outgrower scheme caused farmers to move back to subsistence and led to reductions in cotton yields of around $43-45 \%$. The improvement of the outgrower scheme in 2001-2002 reversed these trends: farmers allocated more land to cotton, and yields per hectare increased by $18 \%$ (beyond the base period levels of the introductory phase).

At least three lessons can be derived from our analysis. First, our findings emphasize the importance of exploring the medium-run impacts, on top of the more standard short-run costs and benefits, of the privatization of marketing boards in Africa. Second, the results generate valuable evidence on how this type of marketing reforms affects yields at the farm level via input and output prices, credit, input use, technical advice, information and technology, and efficiency. Third, these reforms can foment complex institutions and our work highlights the role of market creation and contract enforcement in the process of economic development and poverty reduction in rural areas in developing countries. 


\section{Acknowledgements}

We wish to thank T. Jayne, J. Nijhoff, and B. Nsemukila for allowing us access to the Post Harvest Survey data collected by the Central Statistical Office in Lusaka, Zambia. We thank J. Altonji, R. Betancourt, M. Duggan, P. Goldberg, S. Jayachandran, A. Khandelwal, T. Miguel, R. Pande, M. Rosenzweig, M. Schündeln, C. Udry, and seminar participants at Berkeley, Di Tella, Lausanne, Maryland, Virginia, Yale, the Econometric Society Winter Meeting and the World Bank for useful comments and discussion. All errors are our responsibility.

\section{Funding}

Research Budget Support grant from the World Bank Research Department.

\section{References}

Altonji, J. (1986) Intertemporal Substitution in Labor Supply: Evidence From Micro Data, Journal of Political Economy, 94, S176-S215.

Balat, J. and G. Porto (2006) Globalization and Complementary Policies. Poverty Impacts in Rural Zambia, in A. Harrison (ed.) Globalization and Poverty, Chicago University Press for the National Bureau of Economic Research, Boston, MA.

Bardhan, P. and C. Udry (1999) Development Microeconomics, Oxford University Press, New York.

Bates, R.H. (1981) Markets and States in Tropical Africa. The Political Basis of Agricultural Policies, University of California Press, Berkeley.

Banerjee, A. and E. Duflo (2000) Reputation Effects and The Limits of Contracting: A Study of the Indian Software Industry, Quarterly Journal of Economics, 115, 989-1017. 
Banerjee, A. and E. Duflo (2005) Growth Theory Through the Lens of Development Economics, in Handbook of Economic Growth, North Holland.

Binswanger, H., and D. Sillers (1983) Risk Aversion and Credit Constraints in Farmers' Decision-Making: A Reinterpretation, Journal of Development Studies, 20, 133-40.

Conley, T. and C. Udry (2010) Learning About a New Technology: Pineapple in Ghana, American Economic Review, 100, 35-69.

de Janvry, A., M. Fafchamps, and E. Sadoulet (1991) Peasant Household Behavious with Missing Markets: Some Paradoxes Explained, Economic Journal, 101, 1400-17.

Dercon, S. (1996) Risk, Crop Choice, and Savings: Evidence from Tanzania, Economic Development and Cultural Change, 33, 485-513.

Dries, L. and J. Swinnen (2004) Foreign Direct Investment, Vertical Integration, and Local Suppliers: Evidence from the Polish Dairy Sector, World Development, 32, 1525-44.

Eswaran, M. and A. Kotwal (1986) Access to Capital and Agrarian Production Organization, Economic Journal, 96, 482-98.

Fafchamps, M. (1992) Cash Crop Production, Food Price Volatility, and Rural Market Integration in the Third World, American Journal of Agricultural Economics, 74, 90-9.

Foster, A. and M. Rosenzweig (1995) Learning by Doing and Learning from Others: Human Capital and Technical Change in Agriculture, Journal of Political Economy, 103, 1176-1209.

Gow, H. and J. Swinnen (2001) Private Enforcement Capital and Contract Enforcement in Transition Economies, American Journal of Agricultural Economics, 83, 686-90.

Greif, A. (1993) Contract Enforceability and Economic Institutions in Early Trade: the Maghribi Traders' Coalition, American Economic Review, 83, 525-48.

Jayne, T. (1994) Do High Food Marketing Costs Constrain Cash Crop Production? Evidence from Zimbabwe, Economic Development and Cultural Change, 30, 387-402. 
Kranton, R. and A. Swamy (2008) Contracts, Hold-Up, and Exports: Textiles and Opium in Colonial India, American Economic Review, 98, 967-89.

Maertens, M. and J. Swinnen (2009) Trade, Standards, and Poverty: Evidence from Senegal, World Development, 37, 16178.

McKenzie, D. and C. Woodruff (2006) Do Entry Costs Provide an Empirical Basis for Poverty Traps? Evidence from Mexican Microenterprises, Economic Development and Cultural Change, 55, 3-42.

McMillan, J. and C. Woodruff (1999) Interfirm Relationships and Informal Credit in Vietnam, Quarterly Journal of Economics, 114, 1285-1320.

Olley, G. and A. Pakes (1996) The Dynamics of Productivity in the Telecommunications Equipment Industry, Econometrica, 64, 1263-97.

Pavcnik, N. (2002) Trade Liberalization, Entry and Productivity Improvements: Evidence From Chilean Plants, Review of Economic Studies, 69, 245-76.

Pitt, M., M. Rosenzweig, and N. Hassan (1990) Productivity, Health, and Inequality in the Intrahousehold Distribution of Food in Low-Income Countries, American Economic Review, 80, 1139-56.

Robinson, P.M. (1988) Root-N-Consistent Semi-Parametric Model, Econometrica, 56, 931-54.

Rosenzweig, M. and H. Binswanger (1993) Wealth, Weather Risk and the Composition and Profitability of Agricultural Investments, The Economic Journal, 103, 56-78.

Rosenzweig, M. and P. Schultz (1987) Fertility and Investment in Human Capital. Estimates of the Consequence of Imperfect Fertility Control in Malaysia, Journal of Econometrics, 36, $163-84$.

Tschirley, D. and S. Kabwe (2007) Cotton in Zambia: 2007 Assessment of its Organization, Performance, Current Policy Initiatives, and Challenges for the Future, Working Paper \#26, Food Security Research Program, Lusaka, Zambia. 
Tschirley, D., C. Poulton, and P. Labaste (2009) Organization and Performance of Cotton Sectors in Africa: Learning from Reform Experience, World Bank, Washington DC.

Udry, C. and S. Anagol (2006) The Return to Capita in Ghana, American Economic Review Papers and Proceedings, 96, 388-93.

Welch, K., M. McMillan and D. Rodrik (2003) When Economic Reform Goes Wrong: Cashews in Mozambique, Brookings Trade Forum 2003. 
Table 1

Post Harvest Survey

(sample sizes)

\begin{tabular}{lcccccc}
\hline \hline Province & 1997 & 1998 & 1999 & 2000 & 2001 & 2002 \\
\hline Central & 654 & 674 & 648 & 795 & 663 & 701 \\
Eastern & 1,225 & 1,197 & 1,255 & 1,437 & 1,248 & 1,292 \\
Southern & 895 & 828 & 835 & 961 & 835 & 850 \\
Lusaka & 246 & 252 & 243 & 244 & 185 & 182 \\
\hline Copperbelt & 370 & 349 & 379 & 464 & 367 & 372 \\
Luapula & 803 & 775 & 799 & 869 & 760 & 761 \\
Northern & 1,211 & 1,190 & 1,348 & 1,551 & 1,293 & 1,376 \\
Nwestern & 409 & 423 & 429 & 543 & 435 & 431 \\
Western & 706 & 648 & 725 & 835 & 699 & 733 \\
\hline Total & 6,519 & 6,336 & 6,661 & 7,699 & 6,485 & 6,698 \\
\hline \hline
\end{tabular}

Table 2

Percentage of Farmers Growing Cotton

1997 - 2002

\begin{tabular}{lcccccc}
\hline \hline Province & 1997 & 1998 & 1999 & 2000 & 2001 & 2002 \\
\hline Central & 24.6 & 22.6 & 16.6 & 10.3 & 14.7 & 20.2 \\
Eastern & 35.2 & 32.7 & 31.7 & 20.4 & 32.1 & 39.0 \\
Southern & 9.9 & 10.7 & 11.7 & 4.3 & 8.8 & 12.8 \\
Lusaka & 5.4 & 3.3 & 4.7 & 0.4 & 5.1 & 8.2 \\
\hline Copperbelt & 0.8 & 0.6 & 0.3 & 0.0 & 0.0 & 0.0 \\
Luapula & 0.0 & 0.0 & 0.0 & 0.0 & 0.0 & 0.0 \\
Northern & 0.0 & 0.1 & 0.0 & 0.0 & 0.0 & 0.0 \\
NWwestern & 0.3 & 0.0 & 0.0 & 0.0 & 0.0 & 0.2 \\
Western & 1.3 & 0.6 & 0.4 & 0.1 & 0.1 & 0.0 \\
\hline Total & 11.0 & 10.4 & 9.4 & 5.4 & 9.0 & 11.6 \\
\hline \hline
\end{tabular}


Table 3

Fraction of Land Allocated to Cotton

$1997-2002$

\begin{tabular}{lcccccc}
\hline \hline Province & 1997 & 1998 & 1999 & 2000 & 2001 & 2002 \\
\hline a) All Farmers & & & & & & \\
\hline Total & 9.2 & 9.3 & 8.1 & 4.3 & 7.6 & 9.9 \\
\hline Central & 12.1 & 10.7 & 6.7 & 3.5 & 6.3 & 8.5 \\
Eastern & 12.4 & 13.0 & 12.3 & 7.2 & 11.9 & 14.6 \\
Southern & 4.1 & 4.2 & 3.7 & 1.3 & 3.2 & 5.1 \\
Lusaka & 2.4 & 1.4 & 1.7 & 0.1 & 1.9 & 3.3 \\
\hline \hline b) Cotton Farmers & & & & & & \\
\hline Total & 38.0 & 40.0 & 37.7 & 34.2 & 37.5 & 37.9 \\
\hline Central & 44.6 & 43.7 & 37.8 & 32.4 & 40.5 & 39.1 \\
Eastern & 35.3 & 39.6 & 39.1 & 35.4 & 37.1 & 37.3 \\
Southern & 38.9 & 35.3 & 31.4 & 28.9 & 35.7 & 38.9 \\
$\quad$ Lusaka & 44.2 & 41.0 & 38.8 & 26.7 & 37.2 & 39.8 \\
\hline \hline
\end{tabular}

Note: Own calculations based on the Post Harvest Surveys 1997-2002.

Table 4

Yields per Hectare in Cotton

$1997-2002$

\begin{tabular}{lcccccc}
\hline \hline Province & 1997 & 1998 & 1999 & 2000 & 2001 & 2002 \\
\hline Total & 6.18 & 6.53 & 6.38 & 6.21 & 6.44 & 6.39 \\
\hline Central & 6.33 & 6.67 & 6.72 & 7.04 & 6.98 & 6.73 \\
Eastern & 6.14 & 6.45 & 6.28 & 6.07 & 6.32 & 6.32 \\
Southern & 6.09 & 6.65 & 6.40 & 5.56 & 6.57 & 6.23 \\
Lusaka & 6.00 & 6.40 & 6.43 & 6.40 & 5.51 & 6.57 \\
\hline \hline
\end{tabular}

Note: Own calculations based on the Post Harvest Surveys 1997-2002. The figures in the table are in logs (so that the difference from one year to the other is the percentage change in yields). 
Table 5

Percentage of Households that Grow Maize $1997-2002$

\begin{tabular}{lcccccc}
\hline \hline Province & 1997 & 1998 & 1999 & 2000 & 2001 & 2002 \\
\hline Central & 90.2 & 92.2 & 93.5 & 94.3 & 94.0 & 93.2 \\
Eastern & 99.9 & 99.5 & 99.2 & 99.5 & 99.7 & 99.6 \\
Southern & 93.5 & 92.0 & 94.4 & 96.3 & 97.3 & 97.6 \\
Lusaka & 100.0 & 99.5 & 98.9 & 100.0 & 98.9 & 99.4 \\
\hline Copperbelt & 96.7 & 94.3 & 90.9 & 93.5 & 93.5 & 93.6 \\
Luapula & 28.5 & 24.3 & 31.6 & 35.1 & 31.8 & 41.1 \\
Northern & 45.1 & 35.9 & 48.8 & 46.9 & 46.9 & 59.3 \\
NWestern & 75.7 & 65.9 & 71.9 & 66.7 & 80.7 & 77.7 \\
Western & 89.9 & 82.2 & 88.5 & 82.6 & 90.1 & 87.2 \\
\hline Total & 76.2 & 72.1 & 76.1 & 76.2 & 77.7 & 80.7 \\
\hline \hline
\end{tabular}

Note: Own calculations based on the Post Harvest Surveys 1997-2002.

Table 6

Percentage of Households that Grow Maize

Conditional on Growing Cotton

1997 - 2002

\begin{tabular}{lcccccc}
\hline \hline Province & 1997 & 1998 & 1999 & 2000 & 2001 & 2002 \\
\hline Central & 96.7 & 95.7 & 95.1 & 100.0 & 97.9 & 99.3 \\
Eastern & 100.0 & 98.4 & 98.7 & 99.7 & 99.5 & 100.0 \\
Southern & 97.6 & 90.5 & 96.8 & 97.4 & 93.1 & 92.4 \\
Lusaka & 100.0 & 100.0 & 88.9 & 100.0 & 100.0 & 100.0 \\
\hline Total & 98.8 & 96.6 & 97.7 & 99.5 & 98.4 & 98.8 \\
\hline \hline
\end{tabular}


Table 7

Cotton Yields: Impacts of the Marketing Reforms

Baseline Regressions

\begin{tabular}{|c|c|c|c|c|c|c|}
\hline & \multicolumn{6}{|c|}{ Cotton Yields } \\
\hline & \multicolumn{2}{|c|}{ Simple Model } & \multicolumn{4}{|c|}{ Controlling for $I$ and $\eta$} \\
\hline & $(1)$ & $(2)$ & $(3)$ & $(4)$ & $(5)$ & (6) \\
\hline Age of head & $\begin{array}{c}0.006 \\
(0.006)\end{array}$ & $\begin{array}{c}0.006 \\
(0.006)\end{array}$ & $\begin{array}{c}0.012 \\
(0.008)\end{array}$ & $\begin{array}{c}0.009 \\
(0.007)\end{array}$ & $\begin{array}{c}0.014 \\
(0.007)^{*}\end{array}$ & $\begin{array}{c}0.010 \\
(0.007)\end{array}$ \\
\hline Age squared & $\begin{array}{l}-0.00008 \\
(0.00006)\end{array}$ & $\begin{array}{l}-0.00009 \\
(0.00006)\end{array}$ & $\begin{array}{c}-0.00014 \\
(0.00008)^{*}\end{array}$ & $\begin{array}{l}-0.00011 \\
(0.00007)\end{array}$ & $\begin{array}{c}-0.00016 \\
(0.00007)^{* *}\end{array}$ & $\begin{array}{c}-0.0001 \\
(0.00007)\end{array}$ \\
\hline Male hh. head & $\begin{array}{c}0.126 \\
(0.040)^{* * *}\end{array}$ & $\begin{array}{c}0.129 \\
(0.040)^{* * *}\end{array}$ & $\begin{array}{c}0.081 \\
(0.047)^{*}\end{array}$ & $\begin{array}{c}0.077 \\
(0.047)^{*}\end{array}$ & $\begin{array}{c}0.092 \\
(0.047)^{* *}\end{array}$ & $\begin{array}{c}0.087 \\
(0.046)^{*}\end{array}$ \\
\hline Family size & $\begin{array}{c}0.103 \\
(0.031)^{* * *}\end{array}$ & $\begin{array}{c}0.078 \\
(0.031)^{* *}\end{array}$ & $\begin{array}{l}-0.033 \\
(0.037)\end{array}$ & $\begin{array}{c}0.006 \\
(0.036)\end{array}$ & $\begin{array}{l}-0.035 \\
(0.036)\end{array}$ & $\begin{array}{c}0.007 \\
(0.046)\end{array}$ \\
\hline Share of males & $\begin{array}{l}-0.002 \\
(0.087)\end{array}$ & $\begin{array}{l}-0.023 \\
(0.086)\end{array}$ & $\begin{array}{l}-0.024 \\
(0.107)\end{array}$ & $\begin{array}{l}-0.031 \\
(0.105)\end{array}$ & $\begin{array}{l}-0.030 \\
(0.106)\end{array}$ & $\begin{array}{c}-0.034 \\
(0.104)\end{array}$ \\
\hline Farm type & $\begin{array}{c}-0.102 \\
(0.038)^{* * *}\end{array}$ & $\begin{array}{l}-0.056 \\
(0.039)\end{array}$ & $\begin{array}{c}0.127 \\
(0.043)^{* * *}\end{array}$ & $\begin{array}{c}0.069 \\
(0.044)\end{array}$ & $\begin{array}{c}0.124 \\
(0.043)^{* *}\end{array}$ & $\begin{array}{c}0.058 \\
(0.043)\end{array}$ \\
\hline Size cotton plot & $\begin{array}{c}-0.29 \\
(0.023)^{* * *}\end{array}$ & $\begin{array}{c}-0.307 \\
(0.023)^{* * *}\end{array}$ & & & & \\
\hline Relative plot size & & & $\begin{array}{c}-0.341 \\
(0.024)^{* * *}\end{array}$ & $\begin{array}{c}-0.373 \\
(0.025)^{* * *}\end{array}$ & $\begin{array}{c}-0.343 \\
(0.024)^{* * *}\end{array}$ & $\begin{array}{c}-0.376 \\
(0.024)^{* * *}\end{array}$ \\
\hline Livestock & $\begin{array}{c}0.137 \\
(0.032)^{* * *}\end{array}$ & $\begin{array}{c}0.095 \\
(0.033)^{* * *}\end{array}$ & $\begin{array}{l}-0.048 \\
(0.038)\end{array}$ & $\begin{array}{c}-0.053 \\
(0.04)\end{array}$ & $\begin{array}{l}-0.063 \\
(0.038)\end{array}$ & $\begin{array}{c}-0.059 \\
(0.039)\end{array}$ \\
\hline Harrows & & $\begin{array}{l}-0.066 \\
(0.046)\end{array}$ & & $\begin{array}{c}-0.06 \\
(0.053)\end{array}$ & & $\begin{array}{l}-0.063 \\
(0.053)\end{array}$ \\
\hline Ploughs & & $\begin{array}{c}0.106 \\
(0.019)^{* * *}\end{array}$ & & $\begin{array}{c}0.048 \\
(0.027)^{*}\end{array}$ & & $\begin{array}{c}0.032 \\
(0.026)\end{array}$ \\
\hline Basal fertilizer & & $\begin{array}{c}0.082 \\
(0.107)\end{array}$ & & $\begin{array}{c}-0.68 \\
(0.261)^{* * *}\end{array}$ & & $\begin{array}{c}-0.705 \\
(0.255)^{* * *}\end{array}$ \\
\hline Top-dressing fert. & & $\begin{array}{c}0.075 \\
(0.104)\end{array}$ & & $\begin{array}{c}-0.658 \\
(0.289)^{* *}\end{array}$ & & $\begin{array}{c}-0.617 \\
(0.281)^{* *}\end{array}$ \\
\hline Cotton price & $\begin{array}{c}0.18 \\
(0.058)^{* * *}\end{array}$ & $\begin{array}{c}0.206 \\
(0.058)^{* * *}\end{array}$ & $\begin{array}{c}0.303 \\
(0.068)^{* * *}\end{array}$ & $\begin{array}{c}0.322 \\
(0.066)^{* * *}\end{array}$ & $\begin{array}{c}0.113 \\
(0.064)^{*}\end{array}$ & $\begin{array}{c}0.063 \\
(0.062)\end{array}$ \\
\hline Constant & $\begin{array}{c}6.812 \\
(0.277)^{* * *}\end{array}$ & $\begin{array}{c}6.858 \\
(0.274)^{* * *}\end{array}$ & $\begin{array}{c}0.378 \\
(0.338) \\
\end{array}$ & $\begin{array}{c}0.608 \\
(0.331)^{*}\end{array}$ & $\begin{array}{c}-1.30 \\
(0.322)^{* * *}\end{array}$ & $\begin{array}{c}-0.936 \\
(0.314)^{* * *} \\
\end{array}$ \\
\hline$F_{1}$ & $\begin{array}{c}-0.101 \\
(0.042)^{* *}\end{array}$ & $\begin{array}{c}-0.113 \\
(0.042)^{* * *}\end{array}$ & $\begin{array}{c}-0.436 \\
(0.049)^{* * *}\end{array}$ & $\begin{array}{c}-0.404 \\
(0.048)^{* * *}\end{array}$ & $\begin{array}{c}-0.511 \\
(0.059)^{* * *}\end{array}$ & $\begin{array}{c}-0.467 \\
(0.058)^{* * *}\end{array}$ \\
\hline$F_{2}$ & $\begin{array}{c}0.106 \\
(0.030)^{* * *}\end{array}$ & $\begin{array}{c}0.141 \\
(0.031)^{* * *}\end{array}$ & $\begin{array}{c}0.144 \\
(0.039)^{* * *}\end{array}$ & $\begin{array}{c}0.181 \\
(0.039)^{* * *}\end{array}$ & $\begin{array}{c}0.158 \\
(0.039)^{* * *}\end{array}$ & $\begin{array}{c}0.190 \\
(0.039)^{* * *}\end{array}$ \\
\hline Observations & 3418 & 3418 & 3418 & 3418 & 3418 & 3418 \\
\hline$R^{2}$ & 0.11 & 0.12 & 0.11 & 0.14 & 0.12 & 0.14 \\
\hline
\end{tabular}

Note: $F_{1}$ and $F_{2}$ measure the different phases of the dynamics of the cotton marketing reforms. $F_{1}$ is a dummy for 1999 and 2000 and captures the failure of the outgrower scheme; $F_{2}$ is dummy for 2001 and 2002 and captures the success of the outgrower scheme. See text for details.

Columns (1) and (2) correspond to a simple model of cotton yields - equation (1) in the text - without controls for aggregate agricultural trends, $I_{t}$, or overall unobserved farm heterogeneity, $\eta_{h t}$. Columns (3) and (4) correspond to equation (3) and control for $I$ and $\eta$, controlling for international cotton prices; Columns (5) and (6) use instead pre-planting cotton prices.

Robust standard errors within parenthesis. Statistical significance: ${ }^{*}, 10 \% ;{ }^{* *}, 5 \% ; * * *, 1 \%$. 
Table 8

Cotton Yields: Impacts of the Marketing Reforms

Compositional Effects Due to Entry and Exit in Cotton Farming

\begin{tabular}{|c|c|c|c|c|c|c|c|}
\hline & \multirow[b]{2}{*}{ (1) } & \multicolumn{3}{|c|}{ Model 1} & \multicolumn{3}{|c|}{ Model 2} \\
\hline & & $\begin{array}{l}\text { Tobit } \\
(2)\end{array}$ & $\begin{array}{l}\text { OLS } \\
(3)\end{array}$ & $\begin{array}{c}\text { Robinson } \\
\quad(4)\end{array}$ & $\begin{array}{c}\text { Tobit } \\
(5)\end{array}$ & $\begin{array}{c}\text { OLS } \\
(6)\end{array}$ & $\begin{array}{c}\text { Robinson } \\
\quad(7)\end{array}$ \\
\hline Age of head & $\begin{array}{c}0.009 \\
(0.007)\end{array}$ & $\begin{array}{c}0.008 \\
(0.007)\end{array}$ & $\begin{array}{c}0.008 \\
(0.007)\end{array}$ & $\begin{array}{c}0.009 \\
(0.008)\end{array}$ & $\begin{array}{c}0.008 \\
(0.007)\end{array}$ & $\begin{array}{c}0.008 \\
(0.007)\end{array}$ & $\begin{array}{c}0.009 \\
(0.008)\end{array}$ \\
\hline Age squared & $\begin{array}{c}-0.0001 \\
(0.00007)\end{array}$ & $\begin{array}{c}-0.0001 \\
(0.00007)\end{array}$ & $\begin{array}{c}-0.0001 \\
(0.00007)\end{array}$ & $\begin{array}{c}-0.0001 \\
(0.00007)\end{array}$ & $\begin{array}{c}-0.0001 \\
(0.00007)\end{array}$ & $\begin{array}{c}-0.0001 \\
(0.00007)\end{array}$ & $\begin{array}{c}-0.0001 \\
(0.00007)\end{array}$ \\
\hline Male hh. head & $\begin{array}{c}0.077 \\
(0.047)^{*}\end{array}$ & $\begin{array}{c}0.092 \\
(0.048)^{*}\end{array}$ & $\begin{array}{c}0.089 \\
(0.047)^{*}\end{array}$ & $\begin{array}{c}0.093 \\
(0.053)^{*}\end{array}$ & $\begin{array}{c}0.094 \\
(0.048)^{*}\end{array}$ & $\begin{array}{c}0.089 \\
(0.047)^{*}\end{array}$ & $\begin{array}{c}0.094 \\
(0.053)^{*}\end{array}$ \\
\hline Family size & $\begin{array}{c}0.006 \\
(0.036)\end{array}$ & $\begin{array}{c}0.018 \\
(0.037\end{array}$ & $\begin{array}{c}0.022 \\
(0.037)\end{array}$ & $\begin{array}{c}0.014 \\
(0.037)\end{array}$ & $\begin{array}{c}0.019 \\
(0.037)\end{array}$ & $\begin{array}{c}0.023 \\
(0.037)\end{array}$ & $\begin{array}{c}0.015 \\
(0.037)\end{array}$ \\
\hline Share of males & $\begin{array}{l}-0.031 \\
(0.105)\end{array}$ & $\begin{array}{l}-0.022 \\
(0.105)\end{array}$ & $\begin{array}{l}-0.025 \\
(0.105)\end{array}$ & $\begin{array}{l}-0.023 \\
(0.102)\end{array}$ & $\begin{array}{l}-0.021 \\
(0.105)\end{array}$ & $\begin{array}{l}-0.025 \\
(0.105)\end{array}$ & $\begin{array}{l}-0.023 \\
(0.102)\end{array}$ \\
\hline Farm type & $\begin{array}{c}0.069 \\
(0.044)\end{array}$ & $\begin{array}{c}0.052 \\
(0.044)\end{array}$ & $\begin{array}{c}0.039 \\
(0.044)\end{array}$ & $\begin{array}{c}0.059 \\
(0.043)\end{array}$ & $\begin{array}{c}0.05 \\
(0.044)\end{array}$ & $\begin{array}{c}0.037 \\
(0.044)\end{array}$ & $\begin{array}{c}0.057 \\
(0.043)\end{array}$ \\
\hline Relative plot size & $\begin{array}{c}-0.373 \\
(0.025)^{* * *}\end{array}$ & $\begin{array}{c}-0.398 \\
(0.030)^{* * *}\end{array}$ & $\begin{array}{c}-0.522 \\
(0.045)^{* * *}\end{array}$ & $\begin{array}{c}-0.398 \\
(0.028)^{* * *}\end{array}$ & $\begin{array}{c}-0.401 \\
(0.029)^{* * *}\end{array}$ & $\begin{array}{c}-0.524 \\
(0.044)^{* * *}\end{array}$ & $\begin{array}{c}-0.40 \\
(0.028)^{* * *}\end{array}$ \\
\hline Livestock & $\begin{array}{c}-0.053 \\
(0.04)\end{array}$ & $\begin{array}{c}-0.038 \\
(0.04)\end{array}$ & $\begin{array}{c}-0.031 \\
(0.04)\end{array}$ & $\begin{array}{l}-0.038 \\
(0.041)\end{array}$ & $\begin{array}{l}-0.036 \\
(0.041)\end{array}$ & $\begin{array}{l}-0.03 \\
(0.04)\end{array}$ & $\begin{array}{l}-0.036 \\
(0.041)\end{array}$ \\
\hline Harrows & $\begin{array}{c}-0.06 \\
(0.053)\end{array}$ & $\begin{array}{l}-0.054 \\
(0.053)\end{array}$ & $\begin{array}{l}-0.053 \\
(0.053)\end{array}$ & $\begin{array}{l}-0.053 \\
(0.048)\end{array}$ & $\begin{array}{l}-0.055 \\
(0.053)\end{array}$ & $\begin{array}{c}-0.06 \\
(0.053)\end{array}$ & $\begin{array}{l}-0.053 \\
(0.048)\end{array}$ \\
\hline Ploughs & $\begin{array}{c}0.048 \\
(0.027)^{*}\end{array}$ & $\begin{array}{c}0.053 \\
(0.027)^{*}\end{array}$ & $\begin{array}{c}0.054 \\
(0.027)^{* *}\end{array}$ & $\begin{array}{c}0.053 \\
(0.022)^{* *}\end{array}$ & $\begin{array}{c}0.053 \\
(0.027)^{*}\end{array}$ & $\begin{array}{c}0.053 \\
(0.027)^{* *}\end{array}$ & $\begin{array}{c}0.053 \\
(0.022)^{* *}\end{array}$ \\
\hline Basal fertilizer & $\begin{array}{c}-0.68 \\
(0.261)^{* * *}\end{array}$ & $\begin{array}{c}-0.667 \\
(0.260)^{* *}\end{array}$ & $\begin{array}{l}-0.644 \\
(0.258)^{* *}\end{array}$ & $\begin{array}{c}-0.668 \\
(0.255)^{* *}\end{array}$ & $\begin{array}{c}-0.665 \\
(0.260)^{* *}\end{array}$ & $\begin{array}{c}-0.642 \\
(0.258)^{* *}\end{array}$ & $\begin{array}{c}-0.666 \\
(0.255)^{* *}\end{array}$ \\
\hline Top-dressing fert. & $\begin{array}{c}-0.658 \\
(0.289)^{* *}\end{array}$ & $\begin{array}{c}-0.648 \\
(0.287)^{* *}\end{array}$ & $\begin{array}{c}-0.646 \\
(0.284)^{* *}\end{array}$ & $\begin{array}{c}-0.653 \\
(0.281)^{* *}\end{array}$ & $\begin{array}{c}-0.647 \\
(0.286)^{* *}\end{array}$ & $\begin{array}{c}-0.647 \\
(0.284)^{* *}\end{array}$ & $\begin{array}{c}-0.652 \\
(0.280)^{* *}\end{array}$ \\
\hline Cotton price & $\begin{array}{c}0.322 \\
(0.066)^{* * *} \\
\end{array}$ & $\begin{array}{c}0.343 \\
(0.066)^{* * *}\end{array}$ & $\begin{array}{c}0.352 \\
(0.066)^{* * *}\end{array}$ & $\begin{array}{c}0.342 \\
(0.066)^{* * *}\end{array}$ & $\begin{array}{c}0.345 \\
(0.066)^{* * *}\end{array}$ & $\begin{array}{c}0.351 \\
(0.066)^{* * *}\end{array}$ & $\begin{array}{c}0.344 \\
(0.065)^{* * *}\end{array}$ \\
\hline$F_{1}$ & $\begin{array}{c}-0.404 \\
(0.048)^{* * *}\end{array}$ & $\begin{array}{c}-0.429 \\
(0.050)^{* * *}\end{array}$ & $\begin{array}{c}-0.447 \\
(0.049)^{* * *}\end{array}$ & $\begin{array}{c}-0.432 \\
(0.050)^{* * *}\end{array}$ & $\begin{array}{c}-0.431 \\
(0.050)^{* * *}\end{array}$ & $\begin{array}{c}-0.448 \\
(0.049)^{* * *}\end{array}$ & $\begin{array}{c}-0.434 \\
(0.050)^{* * *}\end{array}$ \\
\hline$F_{2}$ & $\begin{array}{c}0.181 \\
(0.039)^{* * *}\end{array}$ & $\begin{array}{c}0.178 \\
(0.039)^{* * *}\end{array}$ & $\begin{array}{c}0.182 \\
(0.039)^{* * *}\end{array}$ & $\begin{array}{c}0.178 \\
(0.040)^{* * *}\end{array}$ & $\begin{array}{c}0.178 \\
(0.039)^{* * *}\end{array}$ & $\begin{array}{c}0.181 \\
(0.039)^{* * *}\end{array}$ & $\begin{array}{c}0.177 \\
(0.040)^{* * *}\end{array}$ \\
\hline$\phi$ & & $\begin{array}{c}0.001 \\
(0.001)\end{array}$ & $\begin{array}{c}0.008 \\
(0.002)^{* * *}\end{array}$ & $\begin{array}{l}- \\
- \\
\end{array}$ & $\begin{array}{c}0.002 \\
(0.001)^{*}\end{array}$ & $\begin{array}{c}0.008 \\
(0.002)^{* * *}\end{array}$ & $\begin{array}{l}- \\
- \\
\end{array}$ \\
\hline Obs & 3418 & 3418 & 3418 & 3418 & 3418 & 3418 & 3418 \\
\hline$R^{2}$ & 0.14 & 0.14 & 0.15 & 0.15 & 0.14 & 0.15 & 0.15 \\
\hline
\end{tabular}

Note: The table reports results on the role of entry and exit into cotton farming on average farm cotton yields. Column (1) reproduces the baseline results from Table 7 (column 4), without accounting for unobserved cotton effects, $\phi$. Tobit, OLS, and partially linear (Robinson) refer to the different procedures used to estimate the cotton share model to derive proxies for $\phi$. See text. $F_{1}$ and $F_{2}$ measure the different phases of the dynamics of the cotton marketing reforms. $F_{1}$ is a dummy for 1999 and 2000 and captures the failure of the outgrower scheme; $F_{2}$ is dummy for 2001 and 2002 and captures the success of the outgrower scheme. See text for details.

Models 1 and 2 correspond to two different first stage models of cotton shares. Model 1 includes (in the first stage) total land tenure, family size, age, age squared, farm type, a dummy for male-headed farms, the proportion of males in the family, a dummy for livestock rasing households, and assets (harrows, ploughs) in monetary units. Model 2 replaces assets (harrows and ploughs) in monetary units for assets in physical units.

Standard errors are bootstrapped (to account for the estimation of $\phi$ ). Statistical significance: *, $10 \% ;{ }^{* *}, 5 \% ; * * *, 1 \%$. 
Table 9

Additional Unobservables in the Selection Model Sensitivity to Measurement Error

\begin{tabular}{lccccccc}
\hline \hline & & \multicolumn{7}{c}{$\sigma_{u}^{2}$} \\
\cline { 2 - 8 } & Baseline & 1 & 4 & 9 & 16 & 25 & 36 \\
\cline { 2 - 8 }$F_{1}$ & -0.429 & -0.429 & -0.429 & -0.430 & -0.430 & -0.431 & -0.431 \\
$F_{2}$ & 0.178 & 0.178 & 0.178 & 0.178 & 0.178 & 0.178 & 0.178 \\
$\phi$ & 0.001 & 0.001 & 0.001 & 0.001 & 0.002 & 0.002 & 0.002 \\
\cline { 2 - 8 } & & 49 & 64 & 81 & 100 & 200 & 300 \\
$n$ & -0.432 & -0.434 & -0.435 & -0.437 & -0.451 & -0.487 \\
$F_{1}$ & 0.178 & 0.178 & 0.178 & 0.178 & 0.176 & 0.173 \\
$F_{2}$ & & 0.002 & 0.002 & 0.002 & 0.002 & 0.003 & 0.005 \\
\hline
\end{tabular}

Note: Estimates impacts of the reforms under different assumptions about the variance of the measurement error, $\sigma_{u}^{2}$, in the cotton shares equation $a_{h t}=\mathbf{z}_{h t}^{\prime} \gamma_{t}+\phi_{h t}+u_{h t}$. Notice that cotton shares are defined on $[0,100)$. The cotton shares equation is estimated with a Tobit regression model (based on Model 1 from Table 8). 
Table 10

Cotton Yields: Impacts of the Marketing Reforms Sensitivity to the Definition of the Reform

\begin{tabular}{|c|c|c|c|c|c|c|}
\hline & \multicolumn{3}{|c|}{ Model 1} & \multicolumn{3}{|c|}{ Model 2} \\
\hline & $(1)$ & $(2)$ & $(3)$ & $(4)$ & $(5)$ & $(6)$ \\
\hline$\phi$ & $\begin{array}{c}0.001 \\
(0.001)\end{array}$ & $\begin{array}{c}0.003 \\
(0.001)^{* * *}\end{array}$ & $\begin{array}{c}0.003 \\
(0.001)^{* * *}\end{array}$ & $\begin{array}{c}0.002 \\
(0.001)^{*}\end{array}$ & $\begin{array}{c}0.003 \\
(0.001)^{* * *}\end{array}$ & $\begin{array}{c}0.003 \\
(0.001)^{* * *}\end{array}$ \\
\hline$F_{1}$ & $\begin{array}{c}-0.429 \\
(0.050)^{* * *}\end{array}$ & & & $\begin{array}{c}-0.431 \\
(0.050)^{* * *}\end{array}$ & & \\
\hline$F_{2}$ & $\begin{array}{c}0.178 \\
(0.039)^{* * *}\end{array}$ & & & $\begin{array}{c}0.178 \\
(0.039)^{* * *}\end{array}$ & & \\
\hline$R_{1}$ & & $\begin{array}{c}-0.541 \\
(0.063)^{* * *}\end{array}$ & & & $\begin{array}{c}-0.546 \\
(0.063)^{* * *}\end{array}$ & \\
\hline$R_{2}$ & & $\begin{array}{c}0.181 \\
(0.039)^{* * *}\end{array}$ & & & $\begin{array}{c}0.18 \\
(0.039)^{* * *}\end{array}$ & \\
\hline Dummy 1998 & & & $\begin{array}{c}0.303 \\
(0.058)^{* * *}\end{array}$ & & & $\begin{array}{c}0.302 \\
(0.058)^{* * *}\end{array}$ \\
\hline Dummy 1999 & & & $\begin{array}{l}-0.147 \\
(0.103)\end{array}$ & & & $\begin{array}{l}-0.147 \\
(0.103)\end{array}$ \\
\hline Dummy 2000 & & & $\begin{array}{c}-0.411 \\
(0.068)^{* * *}\end{array}$ & & & $\begin{array}{c}-0.415 \\
(0.069)^{* * *}\end{array}$ \\
\hline Dummy 2001 & & & $\begin{array}{c}0.152 \\
(0.061)^{* *}\end{array}$ & & & $\begin{array}{c}0.15 \\
(0.061)^{* *}\end{array}$ \\
\hline Dummy 2002 & & & $\begin{array}{c}0.433 \\
(0.057)^{* * *}\end{array}$ & & & $\begin{array}{c}0.432 \\
(0.057)^{* * *}\end{array}$ \\
\hline Observations & 3418 & 3418 & 3418 & 3418 & 3418 & 3418 \\
\hline$R^{2}$ & 0.14 & 0.15 & 0.16 & 0.14 & 0.15 & 0.16 \\
\hline
\end{tabular}

Note: The table reports the impacts of the reform based on different definitions of its phases. Definition 1: $F_{1}$ is a dummy for 1999 and 2000 and captures the failure of the outgrower scheme; $F_{2}$ is dummy for 2001 and 2002 and captures the success of the outgrower scheme. Definition 2: $R_{1}$ captures the failure of the outgrower contract scheme with a dummy for 2000 (while 1999 is included in the introductory phase); $R_{2}$ includes 2001 and 2002 as before. Definition 3: each year from 1998 to 2002 is allowed to have different impacts on cotton yields. $\phi$ is the measure of unobserved cotton specific effects proxied by the residuals from the cotton shares model. In these results, the cotton shares model is estimated with a Tobit procedure.

Models 1 and 2 correspond to two different first stage models of cotton shares. Model 1 includes (in the first stage) total land tenure, family size, age, age squared, farm type, a dummy for male-headed farms, the proportion of males in the family, a dummy for livestock rasing households, and assets (harrows, ploughs) in monetary units. Model 2 replaces assets (harrows and ploughs) in monetary units for assets in physical units.

Bootstrapped standard errors within parenthesis. Statistical significance: *, $10 \%$;*, $5 \%$; **, $1 \%$. 
Fig. 1 Trends in Agricultural Productivity: Maize, Mixed Beans, Millet, Sorghum, Sunflower, and Groundnuts
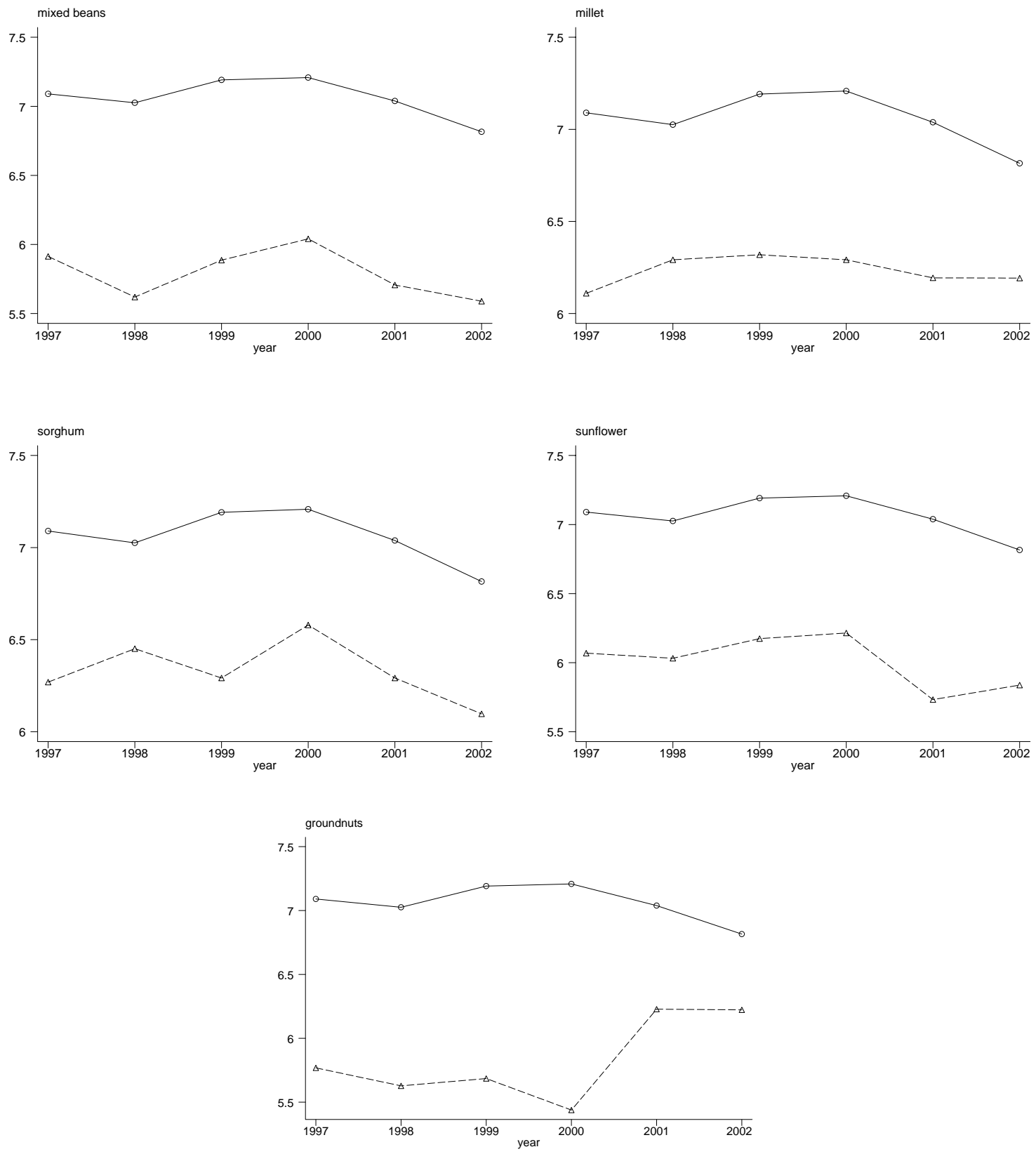

Note: The graphs compare the trend in maize productivity with the trends in productivity in alternative crops. Starting at the top-left, the panels represent the cases of Mixed Beans, Millet, Sorghum, Sunflower, and Groundnuts, respectively. In each panel, the solid line represents the trends in maize productivity and the broken line, the trend in the productivity in the alternative crops. 
Fig. 2 Cotton and Maize Yields in Africa: Zambia, Malawi, Zimbabwe, and Mozambique
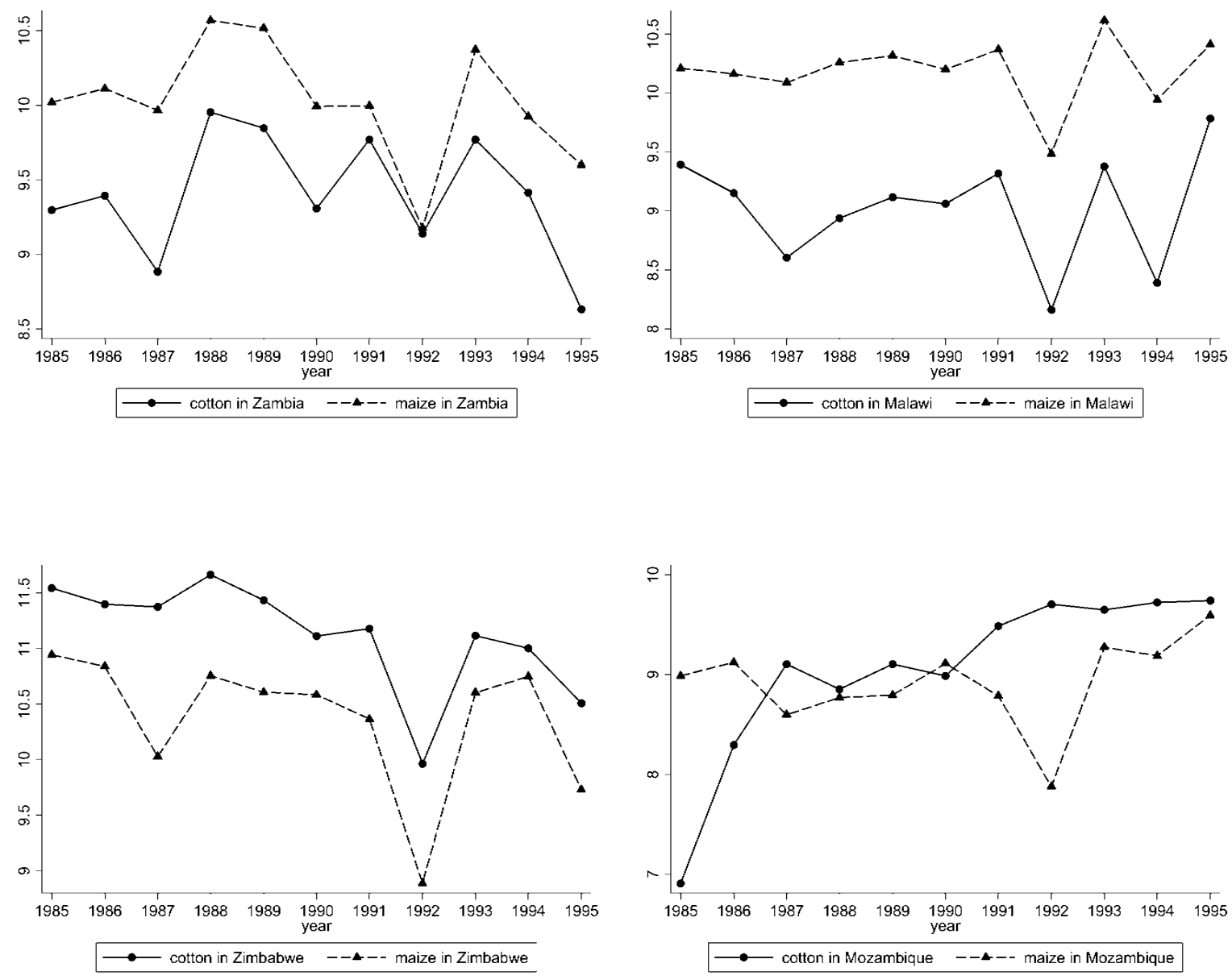

Note: Authors' calculations based on FAO database (FAOSTAT). The graphs depict the overall trends in cotton and maize in Zambia, Malawi, Mozambique, and Zimbabwe. The variables represent the log of output so that differences from one year to another is the growth rate. 
Fig. 3 Trends in Maize Productivity: Reform Provinces versus Non-Reform Provinces

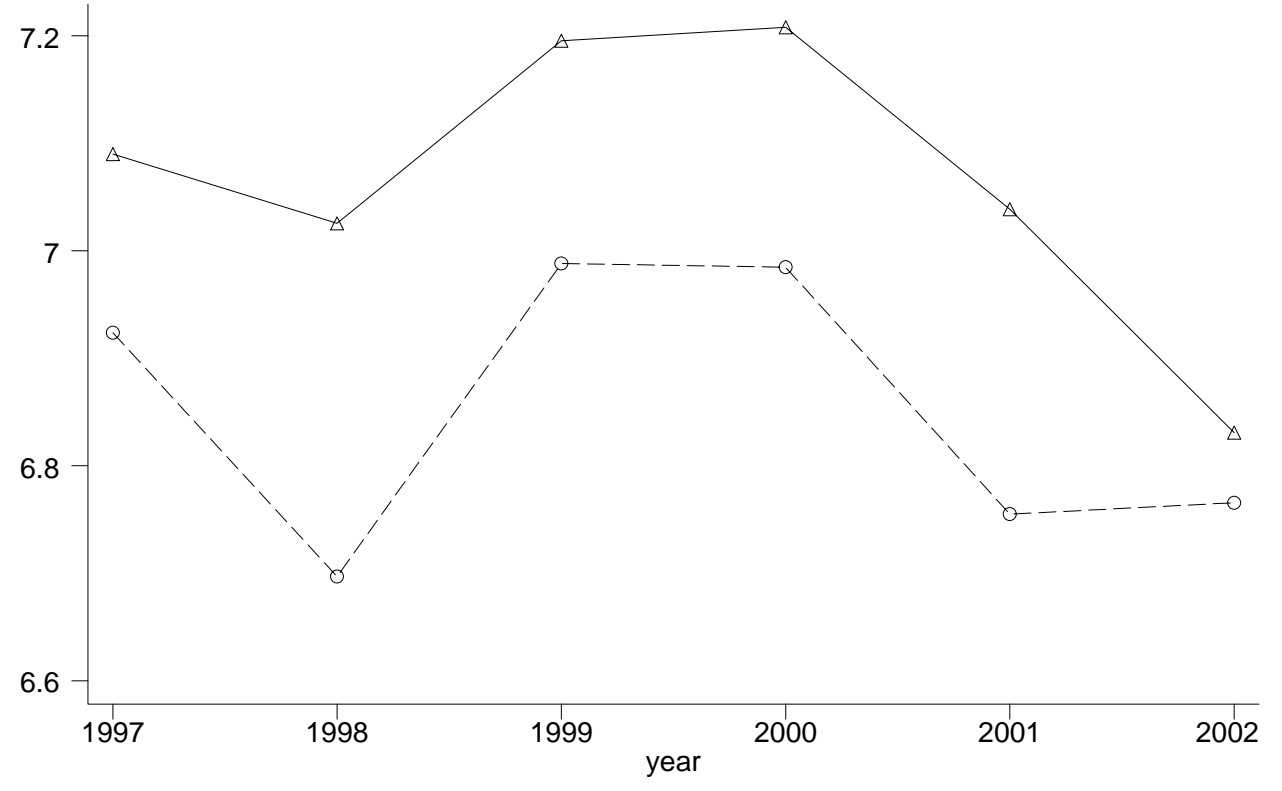

Note: The graph reports the trends in maize productivity in reform provinces (solid line) and non-reform provinces (broken line). Estimates based on the Post Harvest Survey. 
Fig. 4 Average Productivity: Entry and Exit into Cotton Farming

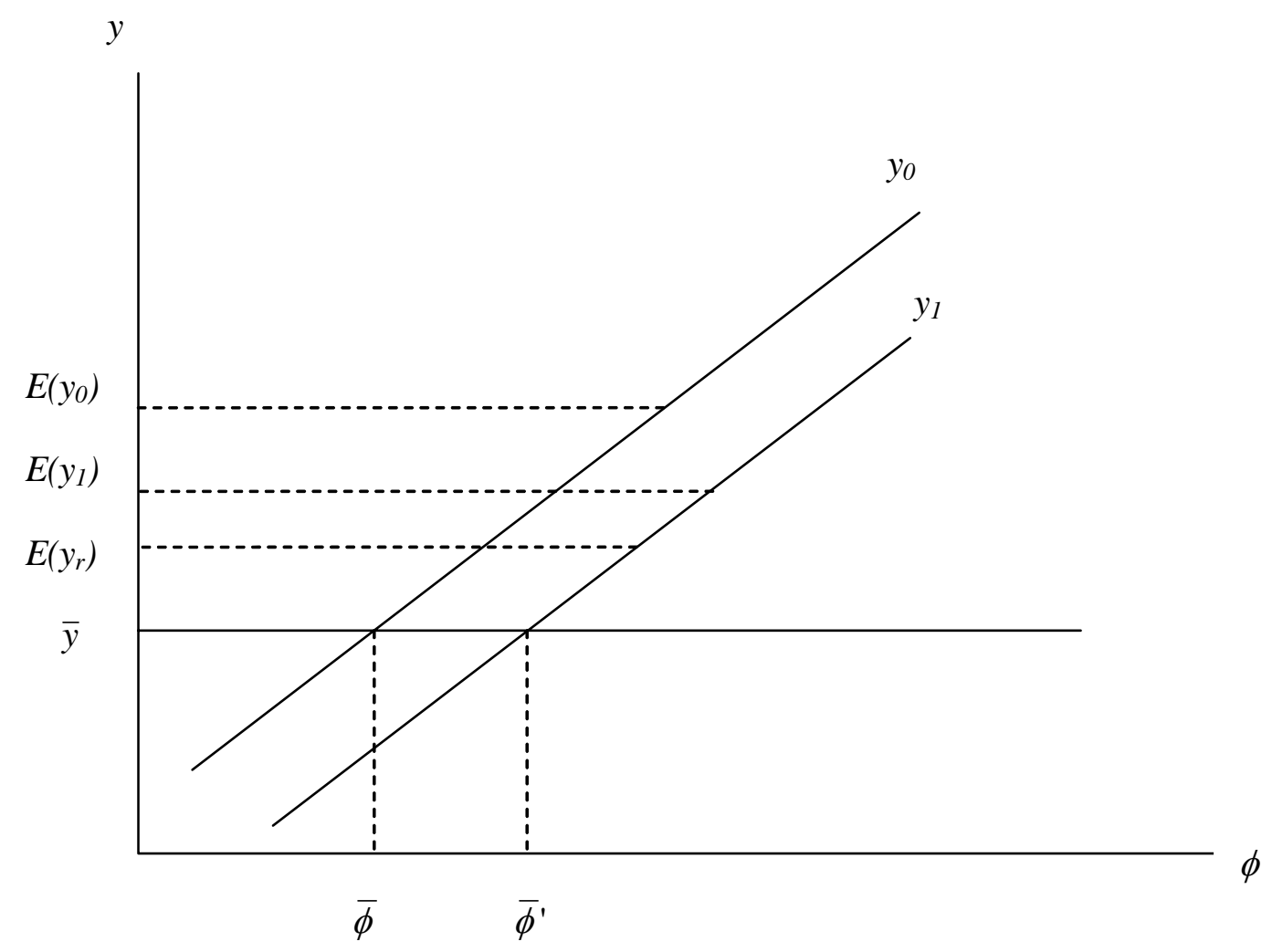

